\title{
DESIGN AND STUDY OF DIMENSIONAL PARAMETERS INFLUENCE ON VORTEX TUBE BEHAVIOR
}

\author{
F. P. Branco, ABSTRACT \\ E. D. Buchelt, \\ F. M. Barbosa, \\ Vortex tube is a thermodynamic device, with no moving parts, applied to \\ separate hot and cold air from compressed air injected into the tube. It has \\ many applications in the industry, for example, among others, it can be \\ B. P. Rosa, \\ mentioned electronic systems cooling, machining processes cooling and \\ environmental chambers. This paper presents the design and tube \\ dimensioning based on parameters and data found in the literature. \\ Therefore, a prototype has been made and tested, which allowed the \\ understanding of the influence of internal tube diameter and width on the \\ hot and cold air temperatures while submitted to compressed air with \\ pressure varying from 1 to 2.5bar. Results of tested configurations indicates \\ that the relation between tube length and diameter (L/D) has small influence \\ on vertex tube behavior, meanwhile, $3 / 8^{\prime}$ " tube diameter shows lowest \\ temperatures on cold flow $\left(-6.5^{\circ} \mathrm{C},-8.0^{\circ} \mathrm{C}\right.$ and $\left.-8.5^{\circ} \mathrm{C}\right)$ and higher $\mathrm{COP}(\approx$ \\ $0.15)$. \\ fabiano@ucdb.b \\ erinsond.buchelt@gmail.com \\ montanare@gmail.com \\ probrunorosa@gmail.com \\ daniel.laporte@ucdb.br \\ Received: September 10, 2018 \\ Revised: October 10, 2018 \\ Accepted: November 12, 2018 \\ Keywords: dimensioning; vortex tube; refrigeration
}

\section{NOMENCLATURE}

$\Delta \mathrm{T} \quad$ Difference air temperature, ${ }^{\circ} \mathrm{C}$

$\dot{\mathrm{m}}$ Mass flow rate, $\mathrm{kg} / \mathrm{s}$

$\dot{\mathrm{Q}}$ Heat transfer rate, W

W Compressor isenthropic power, W

A Tube transversal area, $\mathrm{m}^{2}$

$\mathrm{A}_{\mathrm{e}} \quad$ Inlet transversal area, $\mathrm{m}^{2}$

COP Performance coefficient

$\mathrm{C}_{\mathrm{p}} \quad$ Specific heat at constant pressure, $\mathrm{kJ} / \mathrm{kg} . \mathrm{K}$

d Diaphragm diameter, $m$

D Internal main diameter, $m$

$\mathrm{d}_{\mathrm{e}} \quad$ Air inlet diameter, $\mathrm{m}$

L Tube length, $\mathrm{m}$

$\mathrm{P} \quad$ Absolut pressure, $\mathrm{kPa}$

$\mathrm{R} \quad$ Ideal gas constant, $\mathrm{kJ} / \mathrm{kg} . \mathrm{K}$

$\mathrm{T}$ Temperature, ${ }^{\circ} \mathrm{C}$

$\mathrm{v}$ velocity, $\mathrm{m} / \mathrm{s}$

\section{Greek symbols}

$\delta \quad$ Diaphragm dimensionless parameter

$\alpha \quad$ Outlet cone angle, degrees

$\rho \quad$ Density, $\mathrm{kg} / \mathrm{m}^{3}$

$\mu_{\mathrm{c}} \quad$ Cold mass fraction

\section{Subscripts \\ in Inlet \\ c Cold}

h Hot

\section{INTRODUCTION}

Vortex tube is simple equipment, easy to be manufacturing, reliable, with no moving parts. It works with compressed air input which is separated in two flows in different temperatures, one hot and another cold air flow (www.exair.com, accessed: September 17, 2017). It is possible to have temperatures between $-46^{\circ} \mathrm{C}$ and $+127^{\circ} \mathrm{C}$, with air flow from 3.5 and $250 \mathrm{~m}^{3} / \mathrm{h}$ and inlet pressure from 1 to 10 bar. (Ginting et al., 2016; Exair, 2016; Gao et al., 2005)

In theory, vortex tube consists in a cylindrical tube in which the high-pressure gas is injected in to the chamber in radial direction, tangent to the internal surface (Pinar, Uluer and Kirmaci, 2009). Both secondary flows, hot and cold, leaves vortex tube in the axial direction, in the same or opposite sense, depending on the construction concept applied (Valipour and Niazi, 2011). Despite of having many studies about vortex tube functioning, as the references presented in this work, there is no agreement on physical phenomena which results on flow temperature separation (Xue et al., 2012).

Therefore, the aim of this study was to design a vortex tube based on parameters values found in the literature and evaluate thermic performance of the system in function of inlet air pressure and other design. 


\section{THEORY}

As showed in the Fig. 1, vortex tube operation consists in a compressed air applied in the inlet, crossing internally the tube in a region called gyro chamber, moving tangentially on the tube internal wall, and toward to outlet control valve.

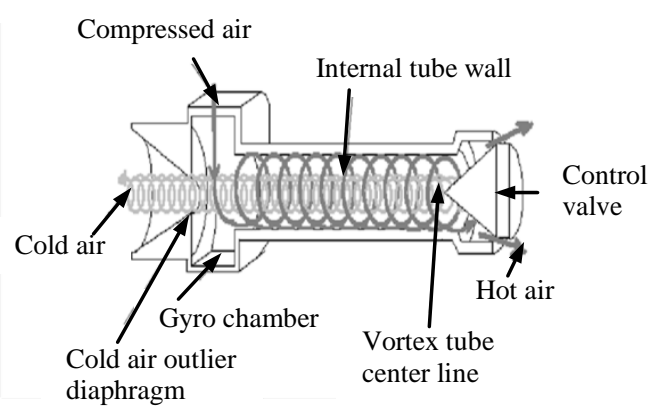

Figure 1. Vortex tube operation scheme. (Gao et al., 2005)

In the outlet, the flow rotation velocity is equal to the inlet, but with less energy compared to the inlet flow, due to lower mass flow in the outlet consequence of the restriction applied by the control valve. This energy loss increases the air temperature in the outlet. In the other hand, another portion from inlet flow is forced backwards in the center of the tube and leaves the tube through the diaphragm. This last one is colder than inlet flow, due to the energy balance in the adopted control volume (Valipour and Niazi, 2011).

Parameters available for dimensioning, shown in Fig. 2, are: Inlet transversal area $\left(\mathrm{A}_{\mathrm{e}}\right)$, tube transversal area (A), tube length $(\mathrm{L})$ and the diaphragm diameter (d), which is the cold air outlet.

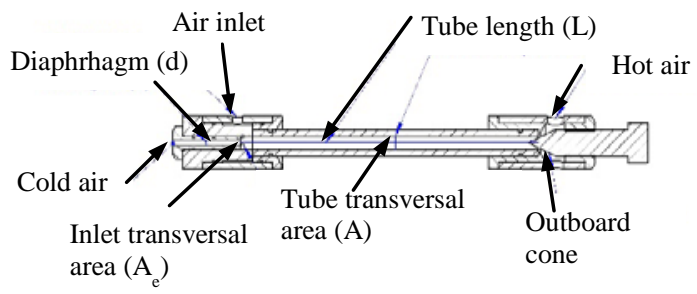

Figure 2. Vortex tube parameters.

Silva (2012) studied the influence of geometric parameters on vortex tube performance. Table 1 summarizes the most important parameters necessary for vortex tube dimensioning.

Table 1. Parameters for vortex tube dimensioning (Silva, 2012).

\begin{tabular}{lcc}
\hline \multicolumn{1}{c}{ Description } & Parameter & Autors \\
\hline $\begin{array}{l}\text { Ratio between orifices } \\
\text { aperture area }\left(\mathrm{A}_{\mathrm{e}}\right) \text { and main } \\
\text { tube transversal area }(\mathrm{A})\end{array}$ & $\mathrm{A}_{\mathrm{e}}=0.17 \mathrm{~A}$ & $\begin{array}{c}\text { Takahama } \\
\text { and Soga } \\
(1966)\end{array}$ \\
\hline
\end{tabular}

\begin{tabular}{lcc}
\hline $\begin{array}{l}\text { Ratio between tube length and } \\
\text { diameter (L/D) }\end{array}$ & $\mathrm{L} / \mathrm{D}=15$ & $\begin{array}{c}\text { Dincer } \text { et al. } \\
(2008)\end{array}$ \\
\hline $\begin{array}{l}\text { Diaphragm dimensionless } \\
\text { parameter }(\delta) \text {, given by ratio } \\
\text { between cold air outlet (d) } \\
\text { and intake air (D) diameters. }\end{array}$ & $\delta=0.5$ & $\begin{array}{l}\text { Bovand } \text { et } \\
\text { al. (2014) }\end{array}$ \\
\hline $\begin{array}{l}\text { Outlet cone angle }(\alpha) \text { of } \\
\text { most efficiency }\end{array}$ & $\alpha=50^{\circ}$ & $\begin{array}{c}\text { Aydin and } \\
\text { Baki } \\
(2006)\end{array}$ \\
\hline
\end{tabular}

\section{EXPERIMENTS}

Vortex tube concept chosen was the contrapuntal flow due to its better efficiency. For designing purposes, it was developed a routine in EES software, which was used to define the initial geometric dimensions, based on literature parameters values, Tab. 1.

For main tube dimensioning, it was considered ratios $\mathrm{L} / \mathrm{D}$ of 12,15 and 18 . Tube diameter was chosen according to aluminum commercial standard dimensions, in which both has $1 / 2$ " of external diameter and internal o 3/8” and 1/4”, Tab. 2 shows each tube dimensions.

Table 2. Tube parameters and ranges: Internal main diameter (D), cold air outlet diameter (d), air inlet diameter $\left(\mathrm{d}_{\mathrm{e}}\right)$ and tube length $(\mathrm{L})$.

\begin{tabular}{cccccc}
\hline $\mathrm{D}$ & $\mathrm{d}$ & $\mathrm{d}_{\mathrm{e}}$ & $\mathrm{L} / \mathrm{D}=12$ & $\mathrm{~L} / \mathrm{D}=15$ & $\mathrm{~L} / \mathrm{D}=18$ \\
\cline { 4 - 6 }$(\mathrm{mm})$ & $(\mathrm{mm})$ & $(\mathrm{mm})$ & & $\mathrm{L}(\mathrm{mm})$ & \\
\hline 9.53 & 4.76 & 2.30 & 114.3 & 142.9 & 171.5 \\
6.35 & 3.18 & 1.50 & 76.2 & 95.2 & 114.3 \\
\hline
\end{tabular}

Thereafter, the tube was designed by means CAD software Solidworks ${ }^{\circledR}$, as shows in Fig. 3, with assembled fixing flanges, which allows easy parts changing for each configuration. Fig. 4 shows manufactured tube.

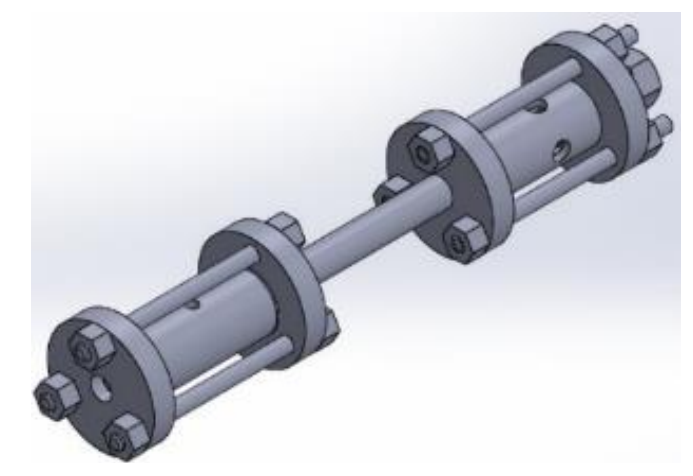

Figure 3. CAD tube design.

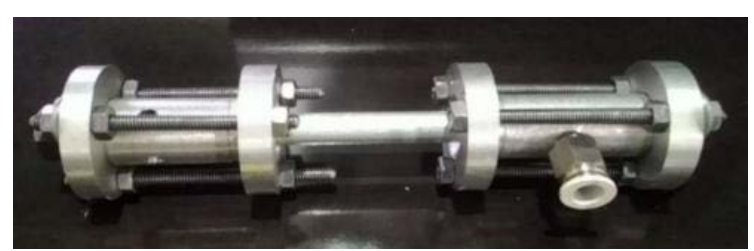

Figure 4. Manufactured tube. 
Vortex tube testing was performed for observing thermic separation phenomenon, by means measuring temperatures of outlet cold air and outlet hot air and comparing them to intake compressed air. Hence, for this purpose, it was chosen penta temperature sensor (Penta III, Full Gauge). Flow rates was also measured by means digital anemometer.

Chosen compressed air source was a piston compressor (Schulz, working pressure up to 4bar and nominal flow rate of $8.82 \mathrm{~m}^{3} / \mathrm{h}$ ). Was applied effective pressure from 1 to $2.5 \mathrm{bar}$, regulated by means filter-regulator (FR-1200, Steula).

Experimental bench, assembled with purpose of testing vortex tube performance while varying parameters, is shown in Fig. 5. Thermometers were placed in the compressed air inlet and outlets. One anemometer was placed in the cold air and another in the hot air outlet, in order to measure mass flow rate of both outlets, besides of total flow rate. Outlet cone aperture, control valve, was adjusted by means M12 screw in order to obtain lower temperatures on cold air flow outlet.

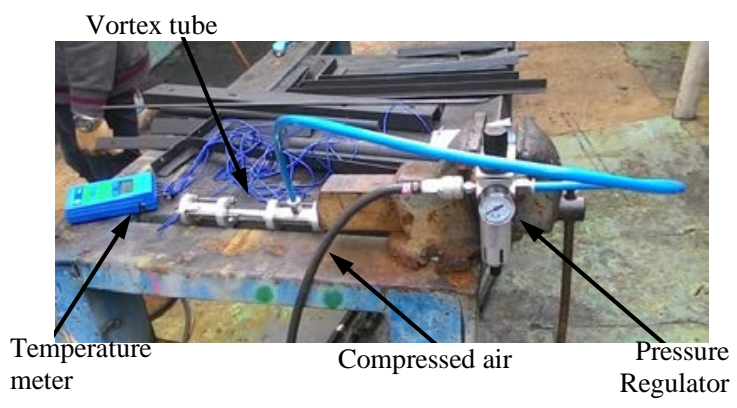

Figure 5. Experimental bench.

The required thermophysical properties were calculated by EES ${ }^{\circledR}$ software. Vortex tube temperature variations are the most important parameters for this type of equipment, as following:

$$
\begin{aligned}
& \Delta \mathrm{T}_{\mathrm{h}}=\mathrm{T}_{\mathrm{h}}-\mathrm{T}_{\mathrm{in}} \\
& \Delta \mathrm{T}_{\mathrm{c}}=\mathrm{T}_{\mathrm{c}}-\mathrm{T}_{\mathrm{in}}
\end{aligned}
$$

Eq. (1) and (2) shows the difference on hot air temperature $\left(\Delta \mathrm{T}_{\mathrm{h}}\right)$ and difference on cold air temperature $\left(\Delta \mathrm{T}_{\mathrm{c}}\right)$, respectively, in which, $\mathrm{T}_{\text {in }}$ is inlet temperature $\left({ }^{\circ} \mathrm{C}\right), \mathrm{T}_{\mathrm{c}}$ is cold air outlet temperature $\left({ }^{\circ} \mathrm{C}\right)$ and $\mathrm{T}_{\mathrm{h}}$ is hot air outlet temperature $\left({ }^{\circ} \mathrm{C}\right)$.

$$
\dot{\mathrm{m}}_{\mathrm{in}}=\dot{\mathrm{m}}_{\mathrm{c}}+\dot{\mathrm{m}}_{\mathrm{h}}
$$

Mass flow rate in the inlet $\left(\dot{\mathrm{m}}_{\mathrm{in}}\right)$, shows in Eq. (3), was found by applying continuity equation by means adding hot $\left(\dot{\mathrm{m}}_{\mathrm{h}}\right)$ and cold $\left(\dot{\mathrm{m}}_{\mathrm{c}}\right)$ outlet flow rates:

$$
\begin{gathered}
\dot{\mathrm{m}}_{\mathrm{c}}=\mathrm{v}_{\mathrm{c}} \mathrm{A}_{\mathrm{c}} \rho_{\mathrm{c}} \\
\dot{\mathrm{m}}_{\mathrm{h}}=4 \mathrm{v}_{\mathrm{h}} \mathrm{A}_{\mathrm{h}} \rho_{\mathrm{h}}
\end{gathered}
$$

In which, mass flow rates $\dot{\mathrm{m}}_{\mathrm{c}}$ and $\dot{\mathrm{m}}_{\mathrm{h}}$, are given by Eq (4) and Eq (5), respectively. $v_{c}$ and $v_{h}$ are flow velocities of cold and hot outlets $(\mathrm{m} / \mathrm{s})$, respectively; A is diaphragm orifice area $\left(\mathrm{m}^{2}\right) ; \rho$ is air density for each air flow $\left(\mathrm{kg} / \mathrm{m}^{2}\right)$. Hot flow rate $\dot{\mathrm{m}}_{\mathrm{h}}$ due to constructive shape of the tube which has 4 outlet orifices.

After each measurement, it is possible to calculate cold mass fraction $\left(\mu_{c}\right)$ given:

$$
\mu_{\mathrm{c}}=\frac{\dot{\mathrm{m}}_{\mathrm{c}}}{\dot{\mathrm{m}}_{\mathrm{in}}}
$$

The cold mass fraction, shows in Eq. (6), is one of the important parameters as it indicates the vortex tube performance and the energy separation in the vortex tube (Pinar, Uluer and Kirmaci, 2009).

Performance coefficient (COP) of vortex tube might be determined by the ratio between cold heat transfer rate $\left(\dot{\mathrm{Q}}_{\mathrm{c}}\right)$ and compressor isenthropic power $\left(\dot{\mathrm{W}}_{\mathrm{c}}\right)$, given by:

$$
\mathrm{COP}=\frac{\dot{\mathrm{Q}}_{\mathrm{c}}}{\dot{\mathrm{W}}_{\mathrm{c}}}
$$

In which, $\dot{\mathrm{Q}}_{c}$ e $\dot{\mathrm{W}}_{c}$ are given, respectively, by:

$$
\begin{gathered}
\dot{\mathrm{Q}}_{\mathrm{c}}=\dot{\mathrm{m}}_{\mathrm{c}} \mathrm{c}_{\mathrm{p}}\left(\mathrm{T}_{\mathrm{in}}-\mathrm{T}_{\mathrm{c}}\right) \\
\dot{\mathrm{W}}_{\mathrm{c}}=\dot{\mathrm{m}}_{\mathrm{in}} \mathrm{RT}_{\mathrm{in}} \ln \left(\frac{\mathrm{P}_{\mathrm{in}}}{\mathrm{P}_{\mathrm{c}}}\right)
\end{gathered}
$$

In which, $c_{p}$ is air specific heat at constant pressure $(\mathrm{kJ} / \mathrm{kg} . \mathrm{K}), \mathrm{R}$ is gas constant $(\mathrm{kJ} / \mathrm{kg} . \mathrm{K}), \mathrm{P}_{\text {in }}$ is inlet absolute pressure $(\mathrm{kPa})$ e $\mathrm{P}_{\mathrm{c}}$ is cold flow outlet absolut pressure $(\mathrm{kPa})$.

\section{RESULTS AND DISCUSSION}

Table 3 shows experimental data measured for certain inlet pressures $\left(\mathrm{P}_{\text {in }}\right)$, from 1 to $2.5 \mathrm{bar}$, in different vortex tube configuration of ratio L/D (12, 15 e 18) and tube diameter (3/8 e 1/4”). Inlet air temperature $\mathrm{T}_{\text {in }}$ was kept constant at $26^{\circ} \mathrm{C}$, meanwhile lowest cold temperature was $-8.5^{\circ} \mathrm{C}$ and highest hot temperature was $34^{\circ} \mathrm{C}$. During all tests, even at low pressures, it can be observed the air flow temperature separation phenomenon. 
Table 3. Cold air flow temperature $\left(\mathrm{T}_{\mathrm{c}}\right)$, hot air flow temperature $\left(\mathrm{T}_{\mathrm{h}}\right)$ and velocity of each flow.

\begin{tabular}{|c|c|c|c|c|}
\hline \multicolumn{5}{|c|}{$\mathrm{L} / \mathrm{D}=12\left(3 / 8^{\prime \prime}\right)$} \\
\hline $\mathrm{P}_{\text {in }}$ (bar) & $\begin{array}{c}\mathrm{T}_{\mathrm{c}} \\
\left({ }^{\circ} \mathrm{C}\right)\end{array}$ & $\mathrm{v}_{\mathrm{c}}(\mathrm{m} / \mathrm{s})$ & $\begin{array}{c}\mathrm{T}_{\mathrm{h}} \\
\left({ }^{\circ} \mathrm{C}\right)\end{array}$ & $\mathrm{v}_{\mathrm{h}}(\mathrm{m} / \mathrm{s})$ \\
\hline 1.0 & 13.0 & 6.2 & 31.5 & 3.2 \\
\hline 1.5 & 10.0 & 7.0 & 32.0 & 3.5 \\
\hline 2.0 & -0.5 & 11.7 & 33.0 & 7.1 \\
\hline 2.5 & -8.0 & 13.4 & 33.0 & 8.8 \\
\hline \multicolumn{5}{|c|}{$\mathrm{L} / \mathrm{D}=15$ (3/8") } \\
\hline $\mathrm{P}_{\text {in }}$ (bar) & $\begin{array}{c}\mathrm{T}_{\mathrm{c}} \\
\left({ }^{\circ} \mathrm{C}\right) \\
\end{array}$ & $\mathrm{v}_{\mathrm{c}}(\mathrm{m} / \mathrm{s})$ & $\begin{array}{c}\mathrm{T}_{\mathrm{h}} \\
\left({ }^{\circ} \mathrm{C}\right) \\
\end{array}$ & $\mathrm{v}_{\mathrm{h}}(\mathrm{m} / \mathrm{s})$ \\
\hline 1.0 & 16.0 & 6.2 & 30.0 & 3.2 \\
\hline 1.5 & 10.0 & 7.0 & 31.0 & 3.5 \\
\hline 2.0 & -0.5 & 11.7 & 31.5 & 7.1 \\
\hline 2.5 & -6.5 & 13.4 & 33.0 & 8.8 \\
\hline \multicolumn{5}{|c|}{$\mathrm{L} / \mathrm{D}=18\left(3 / 8^{\prime \prime}\right)$} \\
\hline $\mathrm{P}_{\text {in }}$ (bar) & $\begin{array}{c}\mathrm{T}_{\mathrm{c}} \\
\left({ }^{\circ} \mathrm{C}\right) \\
\end{array}$ & $\mathrm{v}_{\mathrm{C}}(\mathrm{m} / \mathrm{s})$ & $\begin{array}{c}\mathrm{T}_{\mathrm{h}} \\
\left({ }^{\circ} \mathrm{C}\right) \\
\end{array}$ & $\mathrm{v}_{\mathrm{h}}(\mathrm{m} / \mathrm{s})$ \\
\hline 1.0 & 13.0 & 6.2 & 31.5 & 3.2 \\
\hline 1.5 & -0.5 & 7.0 & 31.5 & 3.5 \\
\hline 2.0 & -3.5 & 11.7 & 31.5 & 7.1 \\
\hline 2.5 & -8.5 & 13.4 & 31.0 & 8.8 \\
\hline
\end{tabular}

\begin{tabular}{ccccc}
\hline \multicolumn{5}{c}{$\mathrm{L} / \mathrm{D}=12(1 / 4 ")$} \\
\hline $\mathrm{P}_{\text {in }}($ bar $)$ & $\begin{array}{c}\mathrm{T}_{\mathrm{c}} \\
\left({ }^{\circ} \mathrm{C}\right)\end{array}$ & $\mathrm{v}_{\mathrm{c}}(\mathrm{m} / \mathrm{s})$ & $\begin{array}{c}\mathrm{T}_{\mathrm{h}} \\
\left({ }^{\circ} \mathrm{C}\right)\end{array}$ & $\mathrm{v}_{\mathrm{h}}(\mathrm{m} / \mathrm{s})$ \\
\hline 1.0 & 14.0 & 6.2 & 32.0 & 3.2 \\
1.5 & 8.0 & 7.0 & 33.0 & 3.5 \\
2.0 & 6.0 & 11.7 & 33.0 & 7.1 \\
2.5 & 4.5 & 13.4 & 32.0 & 8.8 \\
\hline
\end{tabular}

\begin{tabular}{ccccc}
\hline \multicolumn{5}{c}{$\mathrm{L} / \mathrm{D}=15(1 / 4 ")$} \\
\hline $\mathrm{P}_{\text {in }}($ bar $)$ & $\begin{array}{c}\mathrm{T}_{\mathrm{c}} \\
\left({ }^{\circ} \mathrm{C}\right)\end{array}$ & $\mathrm{v}_{\mathrm{c}}(\mathrm{m} / \mathrm{s})$ & $\begin{array}{c}\mathrm{T}_{\mathrm{h}} \\
\left({ }^{\circ} \mathrm{C}\right)\end{array}$ & $\mathrm{v}_{\mathrm{h}}(\mathrm{m} / \mathrm{s})$ \\
\hline 1.0 & 12.0 & 6.2 & 32.0 & 3.2 \\
1.5 & 7.5 & 7.0 & 33.0 & 3.5 \\
2.0 & 5.0 & 11.7 & 34.0 & 7.1 \\
2.5 & -1.5 & 13.4 & 33.0 & 8.8 \\
\hline
\end{tabular}

\begin{tabular}{ccccc}
\hline \multicolumn{5}{c}{$\mathrm{L} / \mathrm{D}=18(1 / 4 ")$} \\
\hline $\mathrm{P}_{\text {in }}(\mathrm{bar})$ & $\begin{array}{c}\mathrm{T}_{\mathrm{c}} \\
\left({ }^{\circ} \mathrm{C}\right)\end{array}$ & $\mathrm{v}_{\mathrm{c}}(\mathrm{m} / \mathrm{s})$ & $\begin{array}{c}\mathrm{T}_{\mathrm{h}} \\
\left({ }^{\circ} \mathrm{C}\right)\end{array}$ & $\mathrm{v}_{\mathrm{h}}(\mathrm{m} / \mathrm{s})$ \\
\hline 1.0 & 15.5 & 6.2 & 32.5 & 3.2 \\
1.5 & 7.0 & 7.0 & 32.5 & 3.5 \\
2.0 & -0.5 & 11.7 & 31.5 & 7.1
\end{tabular}

\begin{tabular}{lllll}
2.5 & -1.0 & 13.4 & 31.0 & 8.8 \\
\hline
\end{tabular}

Figure 6 shows the behavior of cold temperature difference $\Delta T_{c}$, given by Eq. (2), in function of effective inlet pressure for the studied vortex tube geometric configuration. Observed behavior indicates that the difference between cold and hot air flow temperature is higher when higher inlet pressure is applied temperature, i.e., lower cold air flow temperature $T_{c}$ is reached, as observed on Tab. 3. Comparison among the ratios $\mathrm{L} / \mathrm{D}$, under the same tube diameter, are shown in Fig. 6, the angular coefficients shows that there is the tendency of temperature difference been higher as ratio $\mathrm{L} / \mathrm{D}$. From two different tube diameters the3/8" showed better performance, as it delivers higher $\Delta \mathrm{T}_{\mathrm{C}}$ for all input pressure.
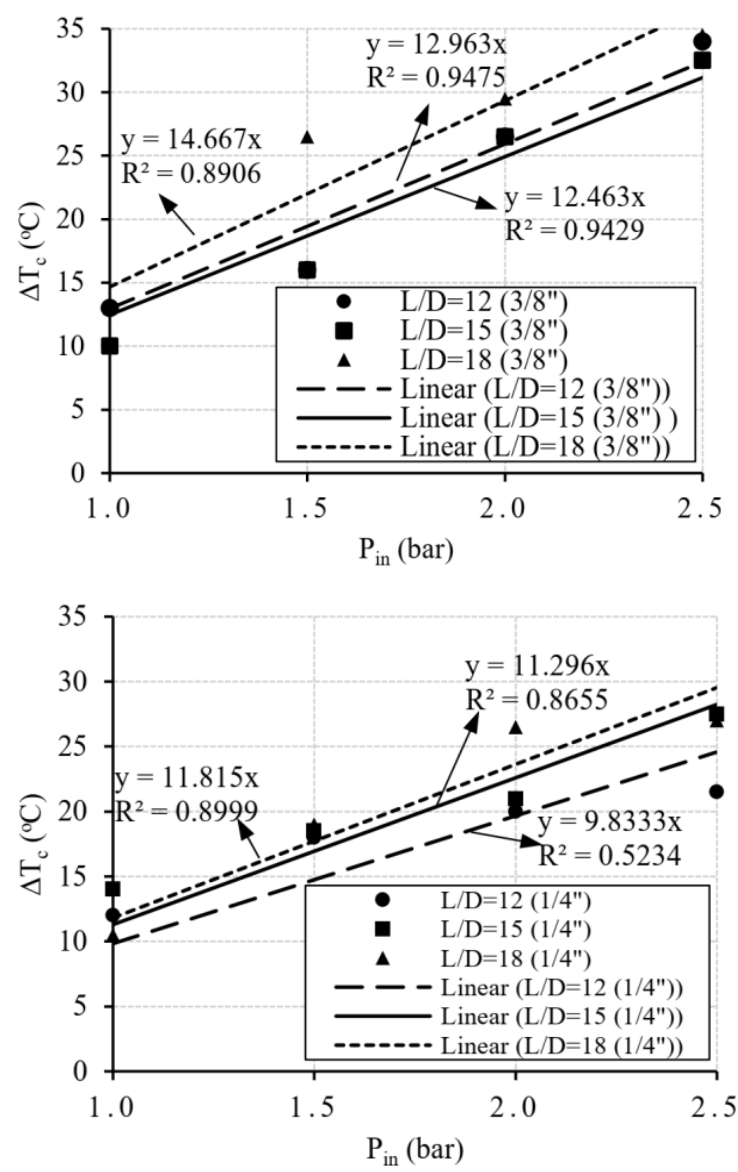

Figure $6 . \Delta$ Tc behavior as a function of vortex tube geometric parameters.

Graphic in Fig. 7 shows the behavior of cold mass fraction $\mu_{c}$ in function of equipment configuration available. This is an important parameter for evaluating vortex tube performance, because it corresponds to the portion of inlet flow at outlet cold flow. For all studied configuration, $\mu_{\mathrm{c}}$ values kept between 0.40 and 0.55 , mainly due to cone adjustments and inlet pressure values. All these adjustments were done to obtain lower outlet cold air 
flow. Cold mass fraction $\mu_{c}$ values obtained are aligned with those presented by Mohammadi e Farhadi (2013) who found better results of $\mu_{c}$ between 0.40 e 0.60 , for inlet pressure about 2.47 bar.
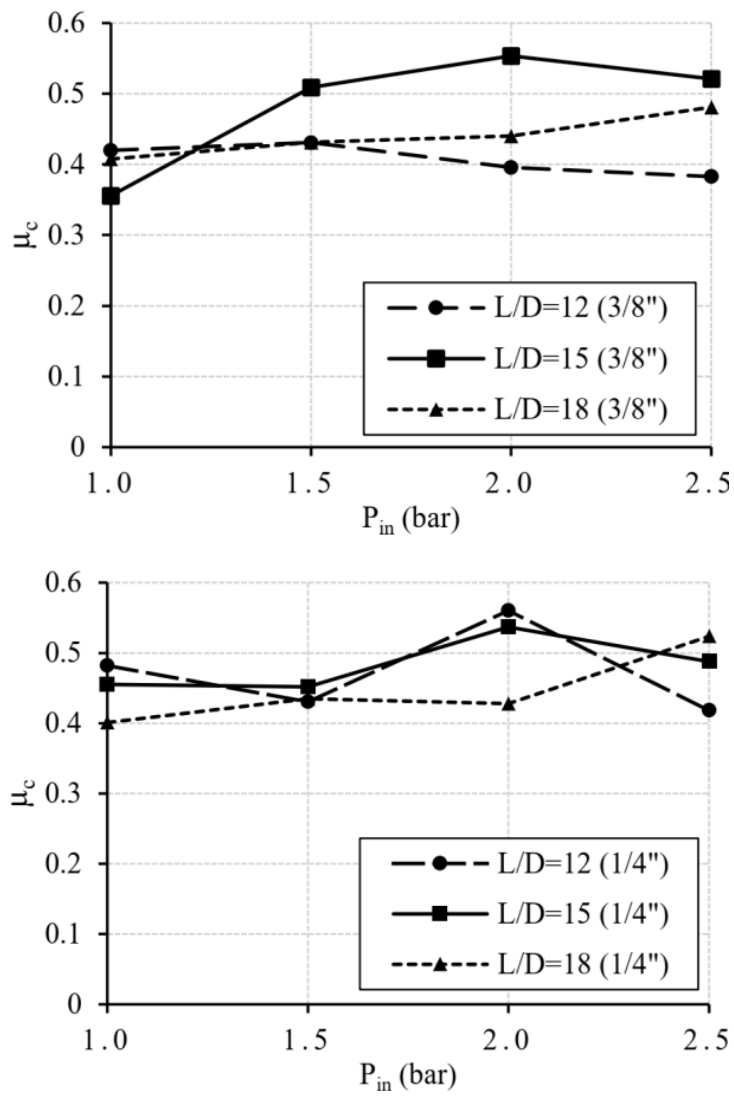

Figure 7. $\mu_{\mathrm{c}}$ behavior as a function of inlet pressure and vortex tube geometric parameters.

Graphics in Fig. 8 shows COP for each inlet pressure, as it can be observed in the linearized curves, the higher COPs are obtained at high pressure (COP about 0.15 at pressure between 2.0 to 2.5 bar) and tubes diameters of $3 / 8$ " also results in higher COPs, for each inlet pressure, when compared to $1 / 4$ " diameter tube. In the same direction, 3/8” tube diameter results in higher $\Delta \mathrm{T}_{\mathrm{c}}$. Another evaluated parameter was $\mathrm{L} / \mathrm{D}$, which has low influence on COP and $\Delta \mathrm{T}_{\mathrm{c}}$, slightly better results was reached with $\mathrm{L} / \mathrm{D}=18$.
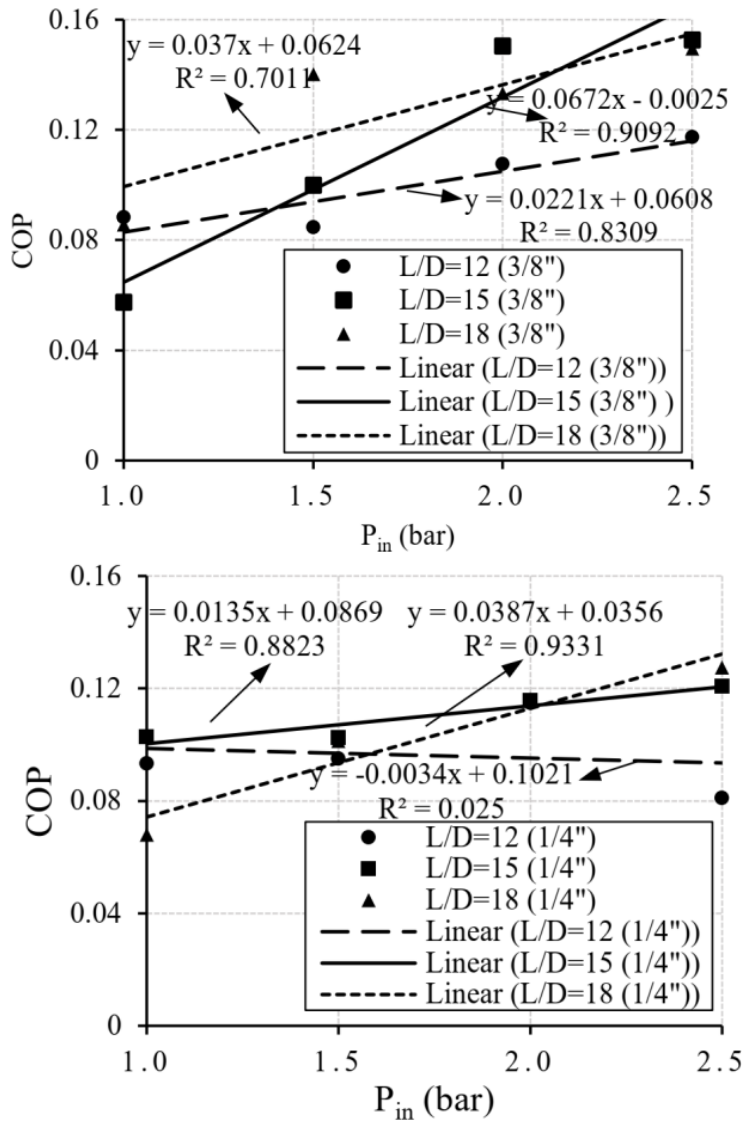

Figure 8. COP behavior as a function of vortex tube geometric parameters.

\section{CONCLUSIONS}

Vortex tube is a simple device, easy for manufacturing and operating, which only needs compressed air source to work. Evaluations performed in this work shows the tube functioning, which splits into two flows, one hot and one cold, the inlet initial flow, even with low inlet pressure values.

The way how it was designed allows modifications in a simple way on the main geometric parameters which has most influence on vortex tube performance, therefore, it is also possible to assembly the equipment for a specific application.

Results of this case of study, about evaluating vortex tube parameters configuration, indicates that the ratio $\mathrm{L} / \mathrm{D}$ has low influence on vortex tube behavior, meanwhile, tests with tube diameter of 3/8" shows the lowest cold flow $\left(-6.5,-8.0\right.$ e $\left.-8.5^{\circ} \mathrm{C}\right)$ and the highest $\mathrm{COP}(\approx 0.15)$.

\section{ACKNOWLEDGEMENTS}

The authors would like to thank UCDB for the financial support and facilities.

\section{REFERENCES}

Aydin, O., and Baki, M., 2006, An 
Experimental Study on the Design Parameters of a Counterflow Vortex Tube, Energy, Vol. 31, No. 14, pp. 2427-2436.

Bovand, M., Valipour, M. S., Dincer, K., and Eiamsa-Ard, S., 2014, Application of Response Surface Methodology to Optimization of a Standard Ranque-Hilsch Vortex Tube Refrigerator, Applied Thermal Engineering, Vol. 67, No. 1-2, pp. 545-553.

Dincer, K., Tasdemir, S., Baskaya, S., and Uysal, B. Z., 2008, Modeling of the Effects of Length to Diameter Ratio and Nozzle Number on the Performance of Counterflow Ranque-Hilsch Vortex Tubes Using Artificial Neural Networks, Applied Thermal Engineering, Vol. 28, No. 17-18, pp. 23802390.

Gao, C. M., Bosschaart, K. J., Zeegers, J. C. H., and De Waele, A. T. A. M., 2005, Experimental Study on a Simple Ranque-Hilsch Vortex Tube, Cryogenics, Vol. 45, No. 3, pp. 173-183.

Ginting, Y. R., Boswell, B., Biswas, W. K., and Islam, M. N., 2016, Environmental Generation of Cold Air for Machining, in: International Scientific Committee of the 13th Global Conference on Sustainable Manufacturing, Vietnamese-German University, Ho Chi Minh City, pp. 649-653.

Mohammadi, S., and Farhadi, F., 2013, Experimental Analysis of a Ranquee-Hilsch Vortex Tube for Optimizing Nozzle Numbers and Diameter, Applied Thermal Engineering, Vol. 61, No. 2, pp. 500-506.

Pinar, A. M., Uluer, O., and Kirmaci, V., 2009, Optimization of Counter flow Ranque-Hilsch Vortex Tube Performance Using Taguchi Method, International Journal of Refrigeration, Vol. 32, No. 6, pp. 1487-1494.

Silva, G. M. A. de M., 2012, Dimensionamento, Construção e Realização de Testes de Desempenho de um Tubo de Vórtice que Opere em Baixas Pressões para Acionamento por Energia Solar, Master Thesis, Universidade Federal do Ceará, Fortaleza, CE. (in Portuguese)

Singh, P. K., Tathgir, R. G., Gangacharyulu, D., and Grewal, G. S., 2004, An Experimental Performance Evaluation of Vortex Tube, Journal of the Institution of Engineers, India, Vol. 84 (January), pp. 149-153.

Takahama, H., and Soga, N., 1966, Studies on Vortex Tubes 2nd Report, Reynolds no. the Effects of the Cold Air Rate and Partial Admission of Nozzle on the Energy Separation, Bulletin of The Japan Society of Mechanical Engineers, Vol. 9, No. 33, pp. 121-130.

Valipour, M. S., and Niazi, N., 2011, Experimental Modeling of a Curved Ranque-Hilsch Vortex Tube Refrigerator, International Journal of Refrigeration, Vol. 34, No. 4, pp. 1109-1116.

Xue, Y., Arjomandi, M., and Kelso, R., 2012, Experimental Study of the Flow Structure in a Counter Flow Ranque-Hilsch Vortex Tube, International Journal of Heat and Mass Transfer, Vol.
55, No. 21-22, pp. 5853-5860. 